University of Nebraska - Lincoln

DigitalCommons@University of Nebraska - Lincoln

2003

\title{
Breeding Season Avifauna of Prairie Dog Colonies and Non- Colonized Areas in Shortgrass Prairie
}

Stephen L. Winter

United States Fish and Wildlife Service, winters18944@gmail.com

Jack Cully Jr.

United States Geological Survey-BRD, Kansas State University

Jeffrey Pontius

Kansas State University

Follow this and additional works at: https://digitalcommons.unl.edu/usfwspubs

Part of the Aquaculture and Fisheries Commons

Winter, Stephen L.; Cully, Jack Jr.; and Pontius, Jeffrey, "Breeding Season Avifauna of Prairie Dog Colonies and Non-Colonized Areas in Shortgrass Prairie" (2003). US Fish \& Wildlife Publications. 21.

https://digitalcommons.unl.edu/usfwspubs/21

This Article is brought to you for free and open access by the US Fish \& Wildlife Service at DigitalCommons@University of Nebraska - Lincoln. It has been accepted for inclusion in US Fish \& Wildlife Publications by an authorized administrator of DigitalCommons@University of Nebraska - Lincoln. 


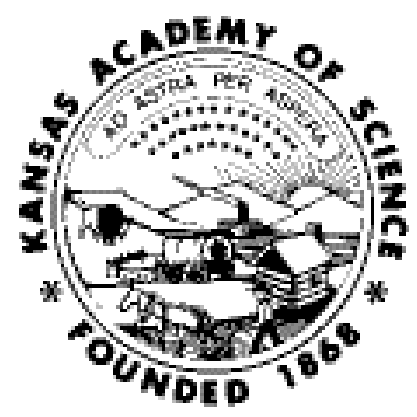

Breeding Season Avifauna of Prairie Dog Colonies and Non-Colonized Areas in Shortgrass Prairie

Author(s): Stephen L. Winter, Jack F. Cully, Jr., Jeffrey S. Pontius

Source: Transactions of the Kansas Academy of Science (1903-), Vol. 106, No. 3/4 (Autumn, 2003), pp. 129-138

Published by: Kansas Academy of Science

Stable URL: http://www.jstor.org/stable/3628393

Accessed: 23/06/2009 00:33

Your use of the JSTOR archive indicates your acceptance of JSTOR's Terms and Conditions of Use, available at http://www.jstor.org/page/info/about/policies/terms.jsp. JSTOR's Terms and Conditions of Use provides, in part, that unless you have obtained prior permission, you may not download an entire issue of a journal or multiple copies of articles, and you may use content in the JSTOR archive only for your personal, non-commercial use.

Please contact the publisher regarding any further use of this work. Publisher contact information may be obtained at http://www.jstor.org/action/showPublisher?publisherCode=ksa.

Each copy of any part of a JSTOR transmission must contain the same copyright notice that appears on the screen or printed page of such transmission.

JSTOR is a not-for-profit organization founded in 1995 to build trusted digital archives for scholarship. We work with the scholarly community to preserve their work and the materials they rely upon, and to build a common research platform that promotes the discovery and use of these resources. For more information about JSTOR, please contact support@jstor.org.

Kansas Academy of Science is collaborating with JSTOR to digitize, preserve and extend access to Transactions of the Kansas Academy of Science (1903-). 


\title{
Breeding season avifauna of prairie dog colonies and non-colo- nized areas in shortgrass prairie
}

\author{
Stephen L. Winter, 'J J A F. Cully, Jr. ${ }^{2}$ and Jeffrey S. Pontius ${ }^{3}$
}

1. US Fish and Wildlife Service, Lower Rio Grande National Wildlife Refuge, Alamo, TX78516 (stephen_winter@fws.gov)

2. USGS-BRD, Kansas Cooperative Fish and Wildlife Research Unit, Division of Biology, Kansas State University, Manhattan, KS 66506

3. Department of Statistics and Kansas State Research and Extension, Kansas State University, Manhattan, KS 66506

\begin{abstract}
Avian assemblages of black-tailed prairie dog (Cynomys ludovicianus) colonies were compared to those present at two types of non-colonized grassland, during the breeding season, in southwestern Kansas and southeastern Colorado. Relative abundances were quantified in 1996 during a period of drought and in 1997 during a period of above average precipitation. We detected fewer bird species at all sites in 1996 than in 1997, and the total number of bird species detected on prairie dog colonies was lower than that detected on both types of non-colonized areas during both years. Horned larks (Eremophila alpestris) had higher relative abundances on non-colonized sites in 1996, but were more abundant on prairie dog colonies in 1997. Lark buntings (Calamospiza melanocorys) and grasshopper sparrows (Ammodramus savannarum) were not recorded at the study sites in 1996, but appeared in high numbers in 1997. These two species, and western meadowlarks (Sturnella neglecta), had higher relative abundances on non-colonized sites in 1997 than on prairie dog colonies. A comparison of our results with those of other studies suggest that the effects of prairie dogs on associated biota might not be identical in all regions of the Great Plains, or under all environmental conditions.
\end{abstract}

Keywords: prairie dogs, grassland birds, shortgrass prairie.

\section{INTRODUCTION}

Prairie dogs (Cynomys spp.), through their burrowing activities and herbivory, have the ability to create localized communities of plants and animals that differ considerably from surrounding grasslands (Whicker and Detling 1988). The importance of prairie dog ecosystems to numerous vertebrates in the Great Plains has been demonstrated (Kotliar, Baker et al. 1999), and increased awareness of this role has prompted appeals for heightened protection of prairie dogs and changes to the management of public and private rangelands (Miller, Wemmer et al. 1990; Miller, Ceballos and Reading 1994;
Davitt, Grandi et al. 1996). In spite of their importance, black-tailed prairie dogs (Cynomys ludovicianus) have declined by $98 \%$ in the past century, and due to continued recent declines, the U.S. Fish and Wildlife Service designated the species as a candidate for listing in 2000 (U.S.D.I. 2000).

Accurate information on how prairie dogs affect flora and fauna in different areas of their range will contribute significantly to land management efforts. To date, only two studies have been conducted which compare the avian assemblages of prairie dog colonies to non-colonized sites (Agnew, Uresk and Hansen 1986; Barko, Shaw and Leslie 1999). 
Our purpose was to quantify differences in breeding season avian assemblages among prairie dog colonies and non-colonized sites in the shortgrass prairie of southwestern Kansas and southeastern Colorado. These findings will enhance prairie dog conservation as well as cooperation of land managers, livestock producers, conservationists, and policy makers in ensuring the maintenance of biotic integrity and economic vitality of western rangelands.

\section{STUdy SITES AND METHOdS}

Study sites were located on Cimarron National Grassland and adjacent private land in Morton County, southwestern Kansas and Baca County, southeastern Colorado. Cimarron National Grassland comprises greater than 43,700 ha of predominantly grazed land administered by the U.S. Forest Service. Most of the surrounding private land is cropped but some areas remain in perennial grass cover and are grazed by cattle. Study sites were on silty loam soils with 0 to $6 \%$ slopes. Study sites were located in a relatively flat landscape north of the Cimarron River, characterized by short and mid-height grasses. Although croplands were adjacent to or near many of the study sites, all study sites were contiguous with larger blocks of grassland vegetation. Woody vegetation in the study landscape was scarce and restricted to plantings around farmsteads, and likely had no measurable influence on our results. Mean yearly precipitation recorded at the Elkhart weather station in Morton County between 1901 and 1996 was $44.75 \mathrm{~cm}$ (National Weather Service Cooperative Observer Network, pers. com.). Precipitation during the 12 months preceding the 1996 sampling period was $34.3 \mathrm{~cm}, 76 \%$ of the long-term mean. Precipitation during the 12 months preceding the 1997 sampling period was 68.0 $\mathrm{cm}, 152 \%$ of the long-term mean.

Whereas many areas at Cimarron National Grassland are characterized by mid-height vegetation, which might reflect the composition of seed mixes used to reclaim abandoned farmland in the 1930s to 1950 s (Schumacher and Atkins 1965), our initial sampling efforts were directed at noncolonized areas that we assumed were characteristic of a shortgrass region. In 1996, we selected for sampling every site we were aware of on Cimarron National Grassland that was dominated by the perennial shortgrasses Bouteloua gracilis and Buchloe dactyloides $(\mathrm{n}=5$, mean $=42.10$ ha, range $=32-64$ ha, total approximately $210 \mathrm{ha}$ ). For comparison we selected eight of the largest prairie dog colonies on Cimarron National Grassland (mean $=41.49$ ha, range $=20-64$ ha, total approximately $332 \mathrm{ha}$ ).

All sites sampled in 1996 were re-sampled in 1997 except two prairie dog colonies; one colony had been destroyed by plague (Cully, Carter and Gage 2000) and the boundaries of the other had changed sufficiently to make it unsuitable for sampling. Completion of the 1996 field season had indicated that it would be logistically possible to sample more sites. In 1997, seven additional prairie dog colonies on Cimarron National Grassland and adjacent private lands $(\mathrm{n}=13$, mean $=39.25 \mathrm{ha}$, range $=8-125$ ha, total approximately 555 ha) and one additional non-colonized shortgrass site on private land $(n=6$, mean $=43.18$ ha, range $=32-64$ ha, total approximately $260 \mathrm{ha}$ ) were sampled.

In 1997, we thought it would be informative to quantify the avian assemblages of a third habitat type present in the study area, noncolonized areas characterized by the presence of mid-height grasses, and compare the data to that of each of the other two treatments in the study. Using a list of potential sites with soil types and slopes identical to those found on the prairie dog colonies, we randomly selected eight non-colonized sites on Cimarron National Grassland for sampling in 1997 (mean $=56.68$ ha, range $=32-64$ ha, total approximately $454 \mathrm{ha}$ ). Data collected 
in 1997 from non-colonized shortgrass sites and non-colonized random sites were not pooled for analyses, each of the noncolonized treatments was analyzed separately.

Vegetation sampling that occurred subsequent to our study (mid-June to mid-July) in 1996 and 1997, demonstrated that each of the three treatments were characterized by distinct vegetation structure and composition (Winter, Cully and Pontius 2002). Dominant vegetation of prairie dog colonies consisted of the perennial shortgrasses Aristida purpurea, Bouteloua gracilis and Buchloe dactyloides. Dominant vegetation of the noncolonized shortgrass sites was Bouteloua gracilis and Buchloe dactyloides, while the vegetation of non-colonized random sites typically included the mid-height perennial grass Bouteloua curtipendula as a codominant with Bouteloua gracilis and Buchloe dactyloides. Vegetation composition during the period when vegetation sampling was conducted likely did not differ greatly from that present one and one-half months earlier when avian sampling occurred during our study. The vegetation that would most likely contribute to a marked seasonal difference, cool season perennial grasses and winter annual grasses, are minor components of the vegetation of this region (Lauenroth and Milchunas 1992), and of our study sites specifically (Winter 1999; Winter, Cully and Pontius 2002).

Strip transects (200 m wide) were established at each study site and varied in length from 0.4 to $1.6 \mathrm{~km}$. One to five parallel transects were sampled at each study site; the length and number of transects varied in proportion to the size of the site, and transects were separated by $250 \mathrm{~m}$. In 1996 we surveyed $12.5 \mathrm{~km}$ of transects on prairie dog colonies and $8.5 \mathrm{~km}$ of transect at non-colonized shortgrass sites. In 1997 we surveyed 11.3 $\mathrm{km}$ of transects on prairie dog colonies, 9.5 $\mathrm{km}$ of transects on non-colonized shortgrass sites and $13.8 \mathrm{~km}$ of transects on non- colonized random sites. We standardized the data to the number of individuals detected $/ \mathrm{km}$ of transect (relative abundance). Relative abundances at each site were used to calculate mean relative abundance for each treatment.

Birds were surveyed along the transects at each study site only once each year, between 27 May and 18 June, and all data were collected by SLW. Data were collected between sunrise and 10:30 am CDST, when it was not raining and winds were less than 30 $\mathrm{km} / \mathrm{hr}$. All sitting, perching and flushing birds, perpendicular or forward of the observer, and within the boundaries of the transect, were recorded. Birds flying over the study site and birds perched on or within $20 \mathrm{~m}$ of livestock watering facilities were not recorded.

Our impression in 1996 was that vegetation structure of the prairie dog colonies was identical to that found on the non-colonized shortgrass sites, and we chose not to measure vegetation structure that year. In 1997, vegetation structure was measured using a visual obstruction pole modified from Robel, Briggs et al. (1970) at randomly located points along each transect. The number of points ranged from 35 to 120 , in proportion to the area of the site. Observations were made one meter from the pole at a height of one meter. Vegetation height was determined by recording the highest point at which vegetation crossed between the observer and the pole. Visual obstruction was determined by recording the lowest point at which the pole was visible.

The response variable for statistical tests was relative abundance, expressed as number of individuals detected per kilometer of transect at each site. Two-tailed tests were used to test null hypotheses that there were no significant differences among the treatments (two treatments in 1996 - prairie dog colonies and non-colonized shortgrass sites; three treatments in 1997 - prairie dog colonies, non-colonized shortgrass sites and 
non-colonized random sites). We chose twotailed tests because we did not want to conduct the study with the assumption that avian abundances would be higher on one treatment than on another, in which case onetailed tests would have been appropriate. For statistical analysis a one-factor analysis of variance (ANOVA), using SAS v. 6.11 proc glm (SAS Institute 1996), was used when the assumptions of the F-test were satisfied. When the assumptions of the F-test were not satisfied, the Kruskal-Wallis nonparametric test, using SAS v. 6.11 proc nparlway (SAS Institute, 1996), and a Tukey-type nonparametric multiple comparison method (Zar 1996) were used. We set $\alpha=0.05$ for hypothesis tests. A test statistic value of $\mathrm{Q}>$ 2.39 generated by the Tukey-type test indicated significant differences. Tables 1 and 2 provide $P$-values from analysis of variance and Kruskal-Wallis tests. When data from three treatments were used in statistical tests, significant $\mathrm{Q}$ and $\mathrm{P}$-values from pairwise comparisons are provided in the text of the results section. In instances where individuals of a particular species were not detected at any study replicates of a particular treatment, that treatment was not included in statistical analyses. This was done because the treatment containing all zeros contributes no within treatment variability to the test statistic but it does contribute to the among treatment variability.

\section{Results}

In 1996, 136 individuals of five species were recorded at prairie dog colonies and 136 individuals of seven species were recorded at the non-colonized shortgrass sites (Table 1). The higher relative abundance of horned larks (Eremophila alpestris) at non-colonized shortgrass sites was significantly different from that found on prairie dog colonies that year. There was no significant difference in the relative abundances of all birds combined, killdeer (Charadrius vociferus), mourning
Table 1. Relative abundance (individuals $/ \mathrm{km}$ of transect) and total number detected (\#) on prairie dog colonies $(n=8)$ and non-colonized shortgrass sites $(n=5)$ in 1996. Model $d f=1$, error $\mathrm{df}=11, \mathrm{P}$-values are from F-tests or Kruskal-Wallis tests. Treatments in which no individuals were detected were not included in statistical tests. Response variable is relative abundance.

\begin{tabular}{|c|c|c|c|c|c|}
\hline & $\begin{array}{l}\text { Prairie dog } \\
\text { colonies }\end{array}$ & & $\begin{array}{l}\text { Shortgrass } \\
\text { sites }\end{array}$ & & \\
\hline & mean $\pm S E$ & $\#$ & mean $\pm S E$ & $\#$ & P-value \\
\hline All birds combined & $11.11 \pm 1.82$ & 136 & $16.07 \pm 1.13$ & 136 & 0.072 \\
\hline $\begin{array}{l}\text { Killdeer } \\
\text { Charadrius vociferus }\end{array}$ & $0.16 \pm 0.16$ & 3 & $0.08 \pm 0.08$ & 1 & 0.523 \\
\hline $\begin{array}{l}\text { Mountain plover } \\
\text { Charadrius montanus }\end{array}$ & 0 & 0 & $0.08 \pm 0.08$ & 1 & \\
\hline $\begin{array}{l}\text { Mourning dove } \\
\text { Zenaida macroura }\end{array}$ & $0.23 \pm 0.16$ & 4 & $0.08 \pm 0.08$ & 1 & 0.692 \\
\hline $\begin{array}{l}\text { Burrowing owl } \\
\text { Athene cunicularia }\end{array}$ & $0.98 \pm 0.76$ & 7 & 0 & 0 & \\
\hline $\begin{array}{l}\text { Common nighthawk } \\
\text { Chordeiles minor }\end{array}$ & 0 & 0 & $0.17 \pm 0.17$ & 2 & \\
\hline $\begin{array}{l}\text { Western kingbird } \\
\text { Tyrannus verticalis }\end{array}$ & 0 & 0 & $0.08 \pm 0.08$ & 1 & \\
\hline $\begin{array}{l}\text { Horned lark } \\
\text { Eremophila alpestris }\end{array}$ & $7.46 \pm 1.45$ & 91 & $14.91 \pm 1.26$ & 123 & 0.005 \\
\hline $\begin{array}{l}\text { Western meadowlark } \\
\text { Sturnella neglecta }\end{array}$ & $2.28 \pm 0.7$ & 31 & $0.66 \pm 0.38$ & 7 & 0.158 \\
\hline
\end{tabular}

doves (Zenaida macroura), and western meadowlarks (Sturnella neglecta) in 1996.

In 1997, 241 individuals of seven species were recorded on prairie dog colonies, 297 individuals of eight species were recorded on non-colonized shortgrass sites, and 552 individuals of nine species were recorded on non-colonized random sites (Table 2). The higher relative abundance of horned larks on prairie dog colonies was significantly different from that found on non-colonized random sites $(P=0.003)$ that year. In 1997 , the higher relative abundance of lark buntings (Calamospiza melanocorys) on noncolonized shortgrass sites was significantly different from that found on prairie dog colonies $(P=0.014)$. The higher relative abundances of all birds combined $(\mathrm{P}=0.001)$, western meadowlarks $(\mathrm{Q}=2.62)$, lark buntings $(\mathrm{P}<0.001)$, and grasshopper sparrows (Ammodramus savannarum, $\mathrm{Q}=$ 
Table 2. Relative abundance (individuals/km of transect), total number detected (\#), and vegetation height and density on prairie dog colonies $(n=13)$, non-colonized shortgrass sites $(n=6)$, and noncolonized random sites $(n=8)$ in 1997. Model $d f=2$, error $\mathrm{df}=24$, P-values are from F-tests or Kruskal Wallis tests. Different superscripts indicate significant differences from pair-wise comparisons. P and Q-values for significantly different pair-wise comparisons are provided in the text. Treatments in which no individuals were detected were not included in statistical tests. Response variable is relative abundance.

\begin{tabular}{|c|c|c|c|c|c|c|c|}
\hline & $\begin{array}{l}\text { Prairie dog } \\
\text { colonies }\end{array}$ & & $\begin{array}{l}\text { Shortgrass } \\
\text { sites }\end{array}$ & & $\begin{array}{l}\text { Random } \\
\text { sites }\end{array}$ & & \\
\hline & mean $\pm S E$ & $\#$ & mean \pm SE & $\#$ & mean $\pm S E$ & $\#$ & P-value \\
\hline All birds combined & $22.59 \pm 1.88^{\circ}$ & 241 & $30.88 \pm 4.20^{\mathrm{ab}}$ & 297 & $40.19 \pm 4.65^{b}$ & 552 & 0.002 \\
\hline $\begin{array}{l}\text { Mountain plover } \\
\text { Charadrius montanus }\end{array}$ & $0.02 \pm 0.02$ & 1 & 0 & 0 & 0 & 0 & \\
\hline $\begin{array}{l}\text { Long-billed curlew } \\
\text { Numenius americanus }\end{array}$ & 0 & 0 & $0.53 \pm 0.31$ & 5 & $0.38 \pm 0.25$ & 5 & 0.452 \\
\hline $\begin{array}{l}\text { Mourning dove } \\
\text { Zenaida macroura }\end{array}$ & $1.11 \pm 0.51$ & 9 & $0.23 \pm 0.16$ & 3 & $0.83 \pm 0.45$ & 10 & 0.717 \\
\hline $\begin{array}{l}\text { Burrowing owl } \\
\text { Athene cunicularia }\end{array}$ & $0.54 \pm 0.24$ & 7 & 0 & 0 & 0 & 0 & \\
\hline $\begin{array}{l}\text { Common nighthawk } \\
\text { Chordeiles minor }\end{array}$ & 0 & 0 & $0.07 \pm 0.07$ & 1 & $0.58 \pm 0.19$ & 7 & 0.054 \\
\hline $\begin{array}{l}\text { Horned lark } \\
\text { Eremophila alpestris }\end{array}$ & $16.48 \pm 1.64^{a}$ & 172 & $10.51 \pm 4.07^{\mathrm{a} b}$ & 101 & $6.78 \pm 1.13^{\circ}$ & 89 & 0.008 \\
\hline $\begin{array}{l}\text { Lark bunting } \\
\text { Calamospiza melanocorys }\end{array}$ & $2.18 \pm 0.97^{a}$ & 32 & $11.92 \pm 3.43^{b}$ & 115 & $18.31 \pm 3.81^{b}$ & 254 & 0.0002 \\
\hline $\begin{array}{l}\text { Grasshopper sparrow } \\
\text { Ammodramus savannarum }\end{array}$ & $0.27 \pm 0.18^{a}$ & 4 & $4.34 \pm 1.49^{\mathrm{ab}}$ & 44 & $8.22 \pm 1.28^{b}$ & 126 & 0.0001 \\
\hline $\begin{array}{l}\text { Dickcissel } \\
\text { Spiza americana }\end{array}$ & 0 & 0 & 0 & 0 & $0.39 \pm 0.39$ & 5 & \\
\hline $\begin{array}{l}\text { Red-winged blackbird } \\
\text { Agelaius phoeniceus }\end{array}$ & 0 & 0 & 0 & 0 & $0.23 \pm 0.23$ & 3 & \\
\hline $\begin{array}{l}\text { Western meadowlark } \\
\text { Sturnella neglecta }\end{array}$ & $1.84 \pm 0.89^{\mathrm{a}}$ & 16 & $2.91 \pm 0.85^{\mathrm{ab}}$ & 26 & $4.19 \pm 0.72^{b}$ & 51 & 0.028 \\
\hline $\begin{array}{l}\text { Brown-headed cowbird } \\
\text { Molothrus ater }\end{array}$ & 0 & 0 & $0.28 \pm 0.28$ & 2 & 0 & 0 & \\
\hline Unidentified species & 0 & 0 & 0 & 0 & $0.26 \pm 0.17$ & 2 & \\
\hline Vegetation height $(\mathrm{cm})$ & $9.48 \pm 0.80^{a}$ & & $25.22 \pm 5.50^{\mathrm{ab}}$ & & $33.59 \pm 3.29^{b}$ & & 0.0008 \\
\hline Visual obstruction $(\mathrm{cm})$ & $2.49 \pm 0.17^{a}$ & & $5.40 \pm 1.22^{\mathrm{ab}}$ & & $6.41 \pm 1.32^{b}$ & & 0.002 \\
\hline
\end{tabular}

4.19) on the non-colonized random sites were significantly different from those found on the prairie dog colonies in 1997. Higher values of vegetation height $(\mathrm{Q}=3.66)$ and visual obstruction $(\mathrm{Q}=3.39)$ on the noncolonized random sites were significantly different from those found on the prairie dog colonies (Table 2) in 1997.

\section{Discussion}

While the sample sizes in our study are relatively small, and sampling occurred only once during each of two years, our results provide useful insight into the ecology of grassland avifauna, and the influence that prairie dogs might have on this community. During the two years of our study, which were characterized by markedly contrasting climatic conditions, we recorded a dramatic difference in the abundances of numerous species, especially lark buntings and grasshopper sparrows. There are numerous reports from throughout the Great Plains of grassland bird populations fluctuating dramatically in association with climatic variation (Wiens 1974; George, Fowler et al. 1992; Igl and Johnson 1995). The drastic population fluctuations that we recorded for lark bunting and grasshopper sparrow might represent a coping strategy whereby their populations are opportunistically "tracking" 
optimum resources over a large scale as they shift in time and space (Wiens 1974; Cody 1985).

Similar to the results of other studies (Agnew, Uresk and Hansen 1986; Barko, Shaw and Leslie 1999; Manzano-Fischer, List and Ceballos 1999), horned larks were the most abundant species on prairie dog colonies that we sampled, comprising $67 \%$ and $71 \%$ of the individuals detected on colonies in 1996 and 1997, respectively. Like Agnew, Uresk and Hansen (1986) and Barko, Shaw and Leslie (1999), we also found burrowing owls (Athene cunicularia) associated only with prairie dog colonies. The relative abundance of burrowing owls on prairie dog colonies, however, was not suitable for statistical analysis because of their total absence from the other treatments. Additional surveys for burrowing owls in Morton and Baca counties, conducted concurrently with our study, found burrowing owls almost exclusively on prairie dog colonies (Winter 1999). Although prairie dog colonies occupied less than $2 \%$ of the land area at Cimarron National Grassland in Morton County in 1997 (J. Chynoweth, USDA Forest Service, pers. com.), burrowing owls were rarely sighted at non-colonized locations, regardless of the sampling or survey methodology (Winter 1999). Prairie dog colonies in our study area appear to be of great importance to burrowing owls during the breeding season.

Our results do not suggest that the number of bird species on prairie dog colonies was higher than that found on non-colonized sites, and this contrasts with the results of research conducted by Agnew, Uresk and Hansen (1986) in South Dakota mixed-grass prairie. In our study, the total number of bird species detected on prairie dog colonies, as well as the number of species $/ \mathrm{km}$ of transect, was lower than that found on non-colonized shortgrass sites in 1996, and lower than that found on non-colonized shortgrass sites and non-colonized random sites in 1997. Further contrasting with the results of Agnew, Uresk and Hansen (1986), in our study relative abundance of all birds combined was statistically similar between colonies and non-colonized shortgrass sites during both years, and higher on non-colonized random sites than on colonies in 1997. Agnew, Uresk and Hansen (1986) consistently found higher abundances of all birds combined on prairie dog colonies than on non-colonized mixedgrass prairie during all sample periods.

Agnew, Uresk and Hansen (1986) reported that abundances of five species [horned lark, mourning dove, killdeer, barn swallow (Hirundo rustica), and burrowing owl] were higher on prairie dog colonies, whereas only three species [red-winged blackbird (Agelaius phoeniceus), upland sandpiper (Bartramia longicauda), and lark bunting] had significantly higher abundances on noncolonized sites. In our study, three species (lark bunting, grasshopper sparrow, and western meadowlark), had a statistically significant higher relative abundance on at least one of the non-colonized treatments than on prairie dog colonies in 1997. In spite of the inability to statistically compare the relative abundances of common nighthawk (Chordeiles minor) on prairie dog colonies and non-colonized random sites in 1997, their relative abundance on non-colonized random sites seems biologically significant and deserves notice. Our data suggest common nighthawk avoid prairie dog colonies, preferring instead the habitat present on noncolonized random sites, which were characterized by mid-height grasses.

Horned lark was the only species in our study to have a statistically significant higher relative abundance on prairie dog colonies than on a non-colonized treatment (prairie dog colonies vs. random sites in 1997). While horned larks were the most abundant species on prairie dog colonies during both years of our study, their abundances were higher on non-colonized shortgrass sites than 
on prairie dog colonies in 1996. In 1997 abundances of horned larks were statistically similar when colonies were compared to noncolonized shortgrass sites. This is surprising, considering this species affinity for habitats characterized by short, sparse vegetation and bare ground (Beason 1995), and previous research in a mixed-grass region which found much higher abundances of horned larks on prairie dog colonies relative to non-colonized areas (Agnew, Uresk and Hansen 1986).

However, the prairie dog colonies and noncolonized shortgrass sites we sampled might have represented habitats for horned larks that are not as dramatically different as colonized and non-colonized habitats in mixed-grass regions.

Vegetation sampling at our study sites in 1996 and 1997, but subsequent to the avian sampling, indicated that prairie dog colonies were characterized by a greater percent cover of forbs, but similar percent cover of grasses and bare ground, than non-colonized shortgrass sites in 1996 (Winter, Cully and Pontius 2002). If these vegetation structural characteristics were present at the time avian sampling occurred as well, forb cover on prairie dog colonies might have provided a visual obstruction that caused prairie dog colonies to be less favored by horned larks during that year. In 1997, when our study found abundances of horned larks were statistically similar between prairie dog colonies and non-colonized shortgrass sites, vegetation height and visual obstruction were similar as well. Additionally, subsequent vegetation sampling that year demonstrated the two treatments also had statistically similar cover of forbs, grasses and bare ground (Winter, Cully and Pontius 2002).

The results of our study, and those of Barko, Shaw and Leslie (1999), suggested that the preference of horned larks for prairie dog colonies or non-colonized grasslands in a shortgrass region might be greatly influenced by the effects of climate on vegetation productivity. During years of high vegetation productivity, there might be a marked contrast between the vegetation structure on prairie dog colonies and that found in adjacent noncolonized shortgrass prairie. During years when vegetation productivity is suppressed by drought, there might be little or no contrast in the vegetation structure of the two habitats.

Because of differences in the characteristic vegetation of shortgrass prairie and mixedgrass prairie, the influence of prairie dogs on bird populations in these two regions might be different. Mixed-grass prairie is characterized by mid-height grasses (Coupland 1992) and the characteristic effect of prairie dog herbivory is the displacement of mid-height grasses by short grasses (Coppock et al. 1983; Archer, Garret and Detling 1987). Both Agnew, Uresk and Hansen (1986) and Archer, Garret and Detling (1987) reported shorter vegetation on prairie dog colonies than non-colonized mixed-grass prairie. The low stature of vegetation on prairie dog colonies provides suitable habitat for species such as horned lark and killdeer, which otherwise might be unable to use mixed-grass prairie because of tall or dense vegetation (Agnew, Uresk and Hansen 1986). Conversely, the ability of prairie dogs to create patches of short-statured vegetation within shortgrass prairie is tempered by the fact that grasslands in this region of the Great Plains are characterized by grasses that are already short (Lauenroth and Milchunas 1992). Bird species that require shortstatured vegetation might find non-colonized shortgrass prairie equally suitable habitat relative to prairie dog colonies.

The extent to which prairie dogs influence the bird community of a region might in large part be a function of the difference in the vegetation structure of prairie dog colonies and non-colonized sites. The vegetation structure of grasslands can be altered by climate, fire, and herbivory (Dix 1960; Sims, Singh and Lauenroth 1978; Brand and Goetz 
1986; Coupland 1992; Lauenroth and Milchunas 1992). These factors, acting alone or together, might negate or enhance the contrast in vegetation structure of prairie dog colonies and associated non-colonized grasslands. The potential for a difference in the vegetation structure of a prairie dog colony and adjacent non-colonized grassland seems much greater in mixed-grass prairie than in shortgrass prairie, where lower precipitation amounts constrain primary productivity. In mixed-grass prairie, prairie dogs can create patches of short-statured vegetation that are attractive to bird species that do not readily use the taller, denser vegetation of associated non-colonized grassland. In shortgrass prairie, there is less of a structural contrast between the vegetation of colonies and non-colonized areas, and both habitats appear suitable for bird species, such as horned larks, that require short-statured vegetation.

\section{ACKnowledgements}

Funding for our project was provided by the U.S. Fish and Wildlife Service, the U.S. Forest Service, and Kansas State University. We especially acknowledge the help and support received from the following people: Bill Gill and Dan Mulhern, U.S. Fish and Wildlife Service; Joe Hartman, Jerry Cline, Nancy Brewer, Dorothy Simmons, and Kirie Willimon, Cimarron National Grassland, U.S. Forest Service; Joyce Brite, Kansas Cooperative Fish and Wildlife Research Unit. Anonymous reviewers provided valuable suggestions that improved our manuscript.

\section{LITERATURE CITED}

Agnew, W., Uresk, D.W. and Hansen, R.M. 1986. Flora and fauna associated with prairie dog colonies and adjacent ungrazed mixed-grass prairie in western South Dakota. Journal Range Management 39, p. 135-139.
Archer, S., Garret, M.G. and Detling, J.K. 1987. Rates of vegetation change associated with prairie dog (Cynomys ludovicianus) grazing in North American mixed-grass prairie. Vegetatio 72 , p. 159166.

Barko, V.A., Shaw, J.H. and Leslie, M.D. Jr. 1999. Birds associated with black-tailed prairie dog colonies in southern shortgrass prairie. Southwestern Naturalist 44, p. 484-489.

Beason, R.C. 1995. Horned lark (Eremophila alpestris). In: The Birds of North America, No. 195 (A. Poole and F. Gill, eds.). The Academy of Natural Sciences, Philadelphia, and the American Ornithologists' Union, Washington, DC.

Brand, M.D. and Goetz, H. 1986. Vegetation of exclosures in southwestern North Dakota. Journal Range Management 39, p. 434-416.

Cody, M.L. 1985. Habitat selection in grassland and open-country birds. Pages 191-226 in M. L. Cody, editor, Habitat selection in birds. Academic Press, Inc. New York, New York.

Coppock, D.L., Detling, J.K., Ellis, J.E. and Dyer, M.I. 1983. Plant-herbivore interactions in a North American mixedgrass prairie I. Effects of black-tailed prairie dogs on intraseasonal aboveground plant biomass and nutrient dynamics and plant species diversity. Oecologia 56, p. 19.

Coupland, R.T. 1992. Mixed prairie. In Coupland, R.T. (ed.), Ecosystems of the World. Vol. 8A, Natural Grasslands: Introduction and Western Hemisphere, p. 151-182. Elsevier Scientific Publishing, Amsterdam.

Cully, J.F. Jr., Carter, L.G. and Gage, K.L. 2000. New records of sylvatic plague in 
Kansas. Journal Wildlife Diseases. 36, p. 389-392.

Davitt, K., Grandi, R., Neasel, C. and Skeele, T. 1996. Conserving prairie dog ecosystems on the Northern Plains: learning from the past to insure the prairie dogs future. Predator Project, Bozeman, Montana.

Dix, R.L. 1960. The effects of burning on the mulch structure and species composition of grasslands in western North Dakota. Ecology 41, p. 49-56.

George, T.L., Fowler, A.C., Knight, R.L. and McEwen, L.C. 1992. Impacts of a severe drought on grassland birds in western South Dakota. Ecological Applications 2, p. 275284.

Igl, L.D. and Johnson, D.H. 1995. Dramatic increase of Le Conte's sparrow in Conservation Reserve Program fields in the northern Great Plains. Prairie Naturalist 27, p. 89-94.

Koford, C.B. 1958. Prairie dogs, whitefaces, and blue grama. Wildlife Monographs No. 3.

Kotliar, N.B., Baker, B.W., Whicker, A.D. and Plumb, G. 1999. A critical review of assumptions about the prairie dog as a keystone species. Environmental Management 24, p. 177-192.

Lauenroth, W.K. and Milchunas, D.G. 1992. Short-grass steppe. In Coupland, R.T. (ed.), Ecosystems of the World. Vol. 8A, Natural grasslands: Introduction and Western Hemisphere, p. 183-226. Elsevier Scientific Publishing, Amsterdam.

Manzano-Fischer, P., List, R. and Ceballos, G. 1999. Grassland birds in prairie-dog towns in northwestern Chihuahua, Mexico. Studies in Avian Biology 19, p. 263-271.
Miller, B., Ceballos, G. and Reading, R. 1994. The prairie dog and biotic diversity. Conservation Biology 8, p. 677-681.

Miller, B., Wemmer, C., Biggens, D. and Reading, R. 1990. A proposal to conserve black-footed ferrets and the prairie dog ecosystem. Environmental Management 14, p. 763-769.

Robel, R.J., Briggs, J.N., Dayton, A.D. and Hulbert, L.C. 1970. Relationships between visual obstruction measurements and weight of grassland vegetation. Journal Range Management 23, p. 295-297.

SAS Institute. 1996. SAS/STAT user's guide, version 6.11. SAS Institute, Cary, North Carolina.

Schumacher, C.M. and Atkins, M.D. 1965. Reestablishment and use of grass in the Morton County, Kansas, land utilization project. U.S. Department of Agriculture, Soil Conservation Service, SCS-TP-146.

Sims, P.L., Singh, J.S. and Lauenroth, W.K. 1978. The structure and function of ten North American Grasslands. I. Abiotic and vegetational characteristics. Journal Ecology 66, p. 251-285.

U.S.D.I. 2000. Endangered and threatened wildlife and plants: 12-month finding for a petition to list the black-tailed prairie dog as threatened. Federal Register 65, p. 5476-5488.

Whicker, A.D. and Detling, J.K. 1988. Ecological consequences of prairie dog disturbances. BioScience 38, p. 778-784.

Wiens, J.A. 1974. Climatic instability and the "ecological saturation" of bird communities in North American grasslands. Condor 76, p. 385-400. 
Winter, S.L. 1999. Plant and breeding bird communities of black-tailed prairie dog colonies and non-colonized areas in southwest Kansas and southeast Colorado. M.S. Thesis. Kansas State University, Manhattan.
Winter, S.L., Cully, J.F. Jr. and Pontius, J.S. 2002. Vegetation of prairie dog colonies and non-colonized shortgrass prairie.

Journal Range Management 55, p. 425-525.

Zar, J.H. 1996. Biostatistical analysis. Prentice-Hall, Inc. Upper Saddle River, New Jersey. 